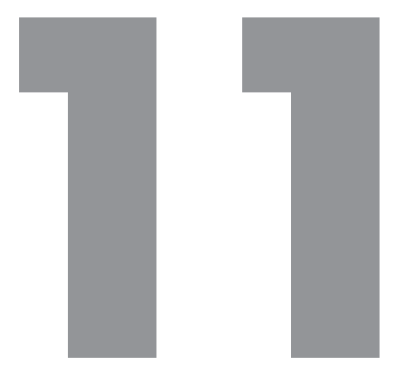

\title{
A EXECUÇÃO E A AÇÃO RESCISÓRIA
}

Nos autos do processo de execução, propriamente, não se comporta defesa, salvo quando cabível a objeção ou exceção de pré-executividade. Assim, a parte ou terceiro que se achar prejudicado em face de atos decisórios do processo de execução poderá opor-se à execução por meio da ação coacta dos embargos à execução.

Portanto, as "defesas" possíveis na execução podem ser veiculadas por petição simples (objeção de pré-executividade) ${ }^{1}$ ou em ação própria (embargos do devedor e embargos de terceiro). O ideal positivado é que os embargos à execução comportem defesa ampla (vide art. 917, VI, do CPC/2015); contudo, dependendo da especificidade, a matéria vai se restringir ao ato que pretende atacar, sendo que a objeção de pré-executividade é a mais restrita de todas, pois, via de regra, trabalha com nulidade flagrante e com prova pré-constituída. ${ }^{2}$ Porém, todas essas modalidades comportam sentença de mérito (inclusive a objeção de

1 A designação de "objeção" parece mais correta. Nessa linha, vide: CÂMARA, Alexandre Freitas. Lições de direito processual civil. 7. ed. Rio de Janeiro: Lumen Juris, 2003. v. II. p. 368.

2 MARTINS, Sandro Gilbert. A defesa do executado por meio de ações autônomas. 2. ed. São Paulo: RT, 2006. p. 270. 
pré-executividade, quando a execução é extinta) ${ }^{3}$ e, como não poderia deixar de ser, podem abrir cabimento à ação rescisória. Uma vez tendo o autor dos embargos (o devedor, por exemplo) formulado o pedido de desconstituição do título executivo, sobrevindo à sentença de procedência e não havendo mais possibilidade de recurso, opera-se a coisa julgada material, atingindo o título executivo. Esse seria um modo direto de se alcançar uma coisa julgada que infirme a instauração do processo de execução. ${ }^{4}$

Não obstante, há formas indiretas de se conseguir uma coisa julgada material que contrarie o processo executivo, com o mesmo poder de fulminá-lo ou inibir seus resultados em face do patrimônio do devedor, tais como ação ordinária de revisão ou repetição do indébito, ação anulatória do título executivo e o mandado de segurança (em se tratando de título executivo originado em ato que possa figurar a autoridade coatora, por exemplo, quando a Fazenda Pública seja o credor). ${ }^{5}$

Nesses casos, uma liminar para paralisar a execução do julgado impugnado ganha especial importância na defesa dos interesses do devedor, que, em casos pontuais, poderá também estar prestes a ser reconhecido legalmente como credor, a propiciar a compensação.

Todas essas modalidades podem produzir a coisa julgada material ${ }^{6}$ e influir significativamente nos resultados da execução, até mesmo chegar a anular por

3 “Em regra, as exceções e objeções de pré-executividade serão julgadas por decisões interlocutórias, contra as quais o recurso adequado será o de agravo de instrumento. Há, porém, a possibilidade de, em razão do acolhimento, a execução ser extinta. Por exemplo: o devedor pode alegar que o título está prescrito ou que é inexequível. Acolhidas as alegações, o juiz extinguirá a execução, por sentença”. (GONÇALVES, Marcus Vinicius Rios. Direito processual civil esquematizado, p. 811).

4 MARINONI, Luiz Guilherme; ARENHART, Sérgio Cruz. Curso de processo civil. São Paulo: RT, 2008. v. 2: Processo de conhecimento, p. 434.

5 Tais instrumentos estão explícitos no art. 38 da Lei n. 6.830/80, por exemplo, listando a admissão em execução da hipótese de ação de repetição, ação anulatória do ato declarativo da dívida e o mandado de segurança. Aliás, o mandado de segurança tributário pode antecipar a defesa que seria oposta na exceção de pré-executividade, porquanto se a certidão da dívida ativa (que é o título executivo tributário, por excelência) restar flagrantemente inexigível, poderá o contribuinte, mediante esse remédio constitucional, obter liminar para vedar a distribuição da execução. Igual hipótese ocorre com base no art. 151, V, do CTN, autorizando-se a tutela antecipada em ação de rito ordinário promovida pelo contribuinte para tal fim. (CHIMENTI, Ricardo Cunha. Lei de execução fiscal comentada e anotada. 5. ed. São Paulo: RT, 2008. p. 199).

6 CÂMARA, Alexandre Freitas. Ação rescisória, p. 31. 
completo os efeitos executórios da sentença já transitada em julgado, como é o caso da procedência de repetição de indébito em que se apure crédito suficiente à compensação integral com o débito.?

Não se trata de rescisão do julgado, mas meios alternativos de defesa do executado. ${ }^{8}$ Em suma, não se procede à ação rescisória para ataque do meritum

7 Não obstante a regra de conexão e continência, para reunião de ações, não se recomenda a propositura de ação anulatória concomitante com os embargos do devedor. Aliás, eventual erro procedimental, na prática, poderá levar a coisas julgadas opostas. Veja-se a esse respeito a seguinte ementa: "Dispõe a lei processual (...) que a propositura de qualquer ação relativa ao débito constante do título executivo não inibe o credor de promover-lhe a execução. (art. 585, $\mathbb{S} 1^{\circ}, \mathrm{VI}$, do CPC). 4. A finalidade da regra é não impedir a execução calcada em título da dívida líquida e certa pelo simples fato da propositura da ação de cognição, cujo escopo temerário pode ser o de obstar o processo satisfativo desmoralizando a força executória do título executivo. 5. À luz do preceito e na sua exegese teleológica colhe-se que a recíproca não é verdadeira; vale dizer: proposta a execução torna-se despicienda e, portanto, falece interesse de agir a propositura de ação declaratória porquanto os embargos interpostos com a mesma causa petendi cumprem os desígnios de eventual ação autônoma. 6. Conciliando-se os preceitos tem-se que, precedendo a ação anulatória, a execução, aquela passa a exercer perante esta inegável influência prejudicial a recomendar o simultaneus processus, posto conexas pela prejudicialidade, forma expressiva de conexão a recomendar a reunião das ações, como expediente apto a evitar decisões inconciliáveis. 7. O juízo único é o que guarda a mais significativa competência funcional para verificar a verossimilhança do alegado na ação de conhecimento e permitir prossiga o processo satisfativo ou se suspenda o mesmo. 8. Refoge à razoabilidade permitir que a ação anulatória do débito caminhe isoladamente da execução calcada na obrigação que se quer nulificar, por isso que, exitosa a ação de conhecimento, o seu resultado pode frustrar-se diante de execução já ultimada. 9. Todavia, revelando-se inviável a junção dos autos da anulatória e da ação de embargos do devedor, pelo fato de encontrar-se findo o primeiro feito (...) evidencia-se a irrelevância de se discutir no presente momento e na via especial, se conexas ou litispendentes as referidas demandas, impondo o desprovimento da irresignação recursal, por ausência de requisito intrínseco de admissibilidade, qual seja, o interesse em recorrer". (STJ REsp 714.792/RS, $1^{\text {a }}$ Turma, Rel. Ministro Luiz Fux, DJ 25.04.2006). Corresponde ao art. 585 do CPC/1973 o art. 784 do CPC/2015.

8 Configura-se erro grosseiro o ajuizamento concomitante de embargos à execução e ação rescisória com o mesmo objetivo. Veja-se a seguinte ementa: "Rescisória - embargos à execução de título extrajudicial - Fundamento no art. 485, incisos V e IX do CPC - Alegações autorais que não se coadunam com esta senda excepcionalíssima; quando muito, próprias de embargos à execução, já opostos e objeto de decisão passada em julgado - Erro de fato só existente quando seu fundamento não é apreciado pela decisão rescindenda - Inocorrência, in casu, porquanto o julgado (com resolução de mérito) abordou a questão fática sobre a qual paira o alegado erro - Pretensa violação a literal dispositivo de lei fundada na mesma tese - Inviável a alegação, se o autor invoca como dispositivos malferidos leis inteiras que regem o assunto, sem apontar 
causae, mas, via oblíqua, é possível conseguir um resultado prático de mesma intensidade com as "defesas" na execução, ou seja, inibir a produção de efeitos na execução em andamento, tendo em vista o reconhecimento de outro direito neutralizador. ${ }^{9}$

especificamente onde residiu a mácula - Ação julgada improcedente”. (TJSP - Ação Rescisória 0081362-15.2009.8.26.0000, Rel. Des. Fernandes Lobo, Comarca: São Paulo, $22^{a}$ Câmara de Direito Privado, julgado em 26.10.2011, registro 18.11.2011). Corresponde ao art. 485, incisos V e IX, do CPC/1973 o art. 966, incisos V e VIII, do CPC/2015.

9 CUNHA, Leonardo Carneiro José da. A Fazenda Pública em juízo. 5. ed. São Paulo: Dialética, 2007. p. 134. 